\title{
Bleeding disorder due to P2Y12 defect
}

INSERM

\section{Source}

INSERM. (1999). Orphanet: an online rare disease and orphan drug data base. Bleeding disorder due to P2Y12 defect. ORPHA:36355

P2Y12 defect is a rare hemorrhagic disorder characterized by mild to moderate bleeding diathesis with easy bruising, mucosal bleedings, and excessive post-operative hemorrhage due to defect of the platelet P2Y12 receptor resulting in selective impairment of platelet responses to adenosine diphosphate. 